\title{
Convenient methods for ingestion of molecular hydrogen: drinking, injection, and inhalation
}

\author{
Ryosuke Kurokawa, Tomoki Seo, Bunpei Sato, Shin-ichi Hirano* and Fumitake Sato
}

\begin{abstract}
Molecular hydrogen $\left(\mathrm{H}_{2}\right)$ is clinically administered; however, in some hospitals, $\mathrm{H}_{2}$ is given to patients without consideration of its safe use. In the present study, we prepared convenient and safe devices for the drinking of super-saturated $\mathrm{H}_{2}$ water, for intravenous drip infusion of $\mathrm{H}_{2}$-rich saline, and for the inhalation of $\mathrm{H}_{2}$ gas. In order to provide useful information for researchers using these devices, the changes in $\mathrm{H}_{2}$ concentration were studied. Our experimental results should contribute to the advance of non-clinical and clinical research in $\mathrm{H}_{2}$ medicine.
\end{abstract}

Keywords: Hydrogen water, Hydrogen-rich saline, Hydrogen gas

\section{Background}

Molecular hydrogen $\left(\mathrm{H}_{2}\right)$ is a medical gas with beneficial effects on oxidative stress [1], inflammation [2], apoptosis [3], lipid metabolism [4], and signaling pathways [5]. More than 280 articles, including 24 articles on clinical studies, have demonstrated that $\mathrm{H}_{2}$ ameliorates the pathological conditions in numerous human diseases [6] or disease models in animals [7], since Ohsawa et al. reported that $\mathrm{H}_{2}$ could be used in antioxidant therapy [8].

$\mathrm{H}_{2}$ is clinically administered through the oral intake of $\mathrm{H}_{2}$ water [9-12], intravenous drip infusion of $\mathrm{H}_{2}$-rich saline [12-15], or inhalation of air with 2-4 $\% \mathrm{H}_{2}$ gas [12]. However, in some hospitals, $\mathrm{H}_{2}$ is given to patients by intravenous drip infusion and/or inhalation without consideration of its safe use. We have developed and provided various devices for the ingestion of $\mathrm{H}_{2}$ to solve this problem. Furthermore, the beneficial effects of $\mathrm{H}_{2}$ using our devices have been reported in 7 human diseases [9-16].

In the present study, we prepared convenient and safe devices for drinking super-saturated $\mathrm{H}_{2}$ water, for intravenous drip infusion of $\mathrm{H}_{2}$-rich saline, and for the inhalation of $\mathrm{H}_{2}$ gas. We examined the changes in $\mathrm{H}_{2}$ concentrations in these devices in order to provide useful information for researchers. Our experimental results

\footnotetext{
*Correspondence: s_hirano@e-miz.co.jp

MiZ Co., Ltd., 2-19-15 Ofuna, Kamakura, Kanagawa 247-0056, Japan
}

reported in this article should contribute to the advance of non-clinical and clinical research in $\mathrm{H}_{2}$ medicine.

\section{Methods/design \\ Materials}

A pressure-resistant $500 \mathrm{~mL}$ PET bottle (e.g., a Coke bottle) was used. $\mathrm{H}_{2}$-generating agent $(0.65 \mathrm{~g})$ was prepared by mixing aluminum powder and calcium hydroxide at a ratio of 76 to 24 by weight. The agent was entirely wrapped with bags, namely, a gas-permeable film or non-woven fabric. The wrapped agent was then reacted with water to generate $\mathrm{H}_{2}$ as follows:

$$
\begin{aligned}
& 2 \mathrm{Al}+\mathrm{Ca}(\mathrm{OH})_{2}+6 \mathrm{H}_{2} \mathrm{O} \rightarrow \mathrm{Ca}\left[\mathrm{Al}(\mathrm{OH})_{4}\right]_{2} \\
& \quad+3 \mathrm{H}_{2} .
\end{aligned}
$$

\section{Preparation of super-saturated $\mathrm{H}_{2}$ water for drinking}

Method I As shown in Fig. 1a and b, a pressureresistant PET bottle $(500 \mathrm{~mL})$, in which gas-permeable film had been directly inserted, was filled with water and then tightly closed. Water in the bottle reacted with the $\mathrm{H}_{2}$-generating agent $(0.65 \mathrm{~g})$, and the $\mathrm{H}_{2}$ gas produced was emitted into the water in the bottle through the gaspermeable film. Thus, during this procedure, the $\mathrm{H}_{2}$ generating agent as well as the water for the reaction did not come into contact with the drinking water. During the reaction, the $\mathrm{H}_{2}$ gas reduced the height of the water level in the standing bottle, which was gradually 


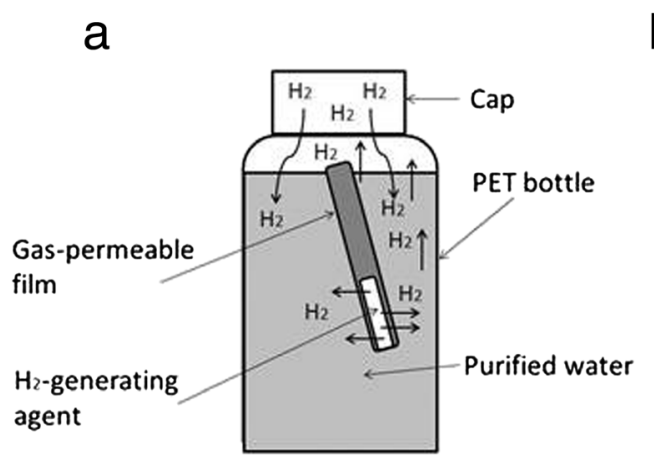

\section{b}

C

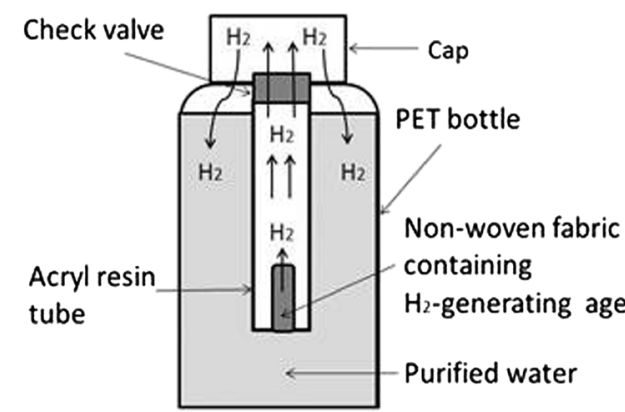

d
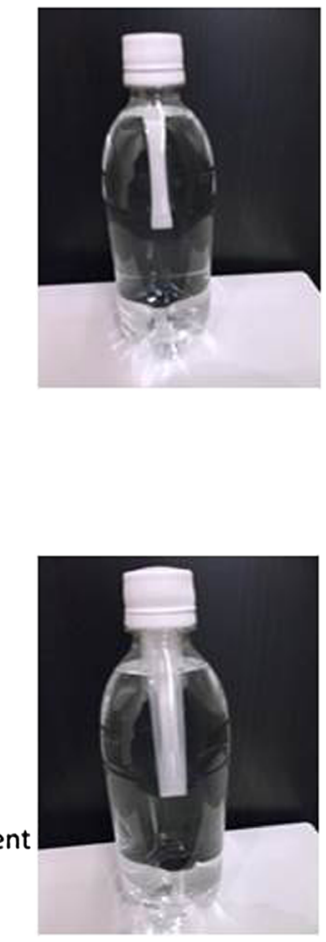

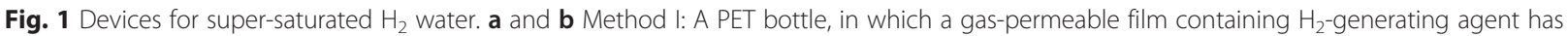
been directly inserted, is filled with water and then tightly closed. The $\mathrm{H}_{2}$ gas produced is emitted into the water in the bottle, lowering the height of the water level, which is then gradually pressurized by the gas. After the reaction is terminated, the $\mathrm{H}_{2}$ gas is dissolved by shaking the bottle. $\mathbf{c}$ and $\mathbf{d}$ Method II: The non-woven fabric containing $\mathrm{H}_{2}$-generating agent is first inserted into an acrylic resin tube, and $0.5 \mathrm{~mL}$ of water is added. The tube is inserted into a PET bottle filled with water. The $\mathrm{H}_{2}$ gas generated in the tube is then transferred to the bottle through the valve

pressurized to approximately 4.5 atmospheric pressures by the gas after $24 \mathrm{~h}$ at room temperature. After the reaction was terminated, the $\mathrm{H}_{2}$ gas was dissolved by shaking the bottle for about $30 \mathrm{~s}$.

Method II Similarly, $\mathrm{H}_{2}$ water was obtained by the use of non-woven fabric. As shown in Fig. 1c and d, the non-woven fabric containing $\mathrm{H}_{2}$-generating agent $(0.65 \mathrm{~g})$ was first inserted into an acrylic resin tube, and $0.5 \mathrm{~mL}$ of water was added. The tube was tightly closed with a cap attached to a check valve, and inserted into a pressure-resistant PET bottle filled with water. $\mathrm{H}_{2}$ generated in the tube was transferred to the bottle through the valve. In about $5 \mathrm{~min}$ at room temperature, the agent started a reaction in the wet fabric. The $\mathrm{H}_{2}$ gas produced was emitted into the water through the check valve attached to the acrylic resin tube. During the reaction, the PET bottle was gradually pressurized to approximately 6 atmospheric pressures due to the generation of $\mathrm{H}_{2}$ gas. After $24 \mathrm{~h}$, the $\mathrm{H}_{2}$ gas was dissolved by shaking the bottle for about $30 \mathrm{~s}$.

\section{Preparation of $\mathrm{H}_{2}$-rich saline for injection}

Method III As shown in Fig. 2a and b, a polyethylene bag for drip infusion, dialysis fluid, or organ storage solution was immersed in a $\mathrm{H}_{2}$-containing water tank where the water was continuously electrolyzed and circulated during the operation. The $\mathrm{H}_{2}$ permeated through the polyethylene film and dissolved in the solution without contamination.

Method IV As shown in Fig. 2c, non-woven fabric containing the $\mathrm{H}_{2}$-generating agent was moistened with a small amount of water, and then both a drip infusion bag and the non-woven fabric were wrapped with aluminum foil under reduced pressure. The water reacted with the agent in the non-woven fabric to generate $\mathrm{H}_{2}$, and the $\mathrm{H}_{2}$ gas permeating through the polyethylene film in the bag dissolved into the solution.

\section{Preparation of $\mathrm{H}_{2}$-containing gas for inhalation}

As shown in Fig. 3, inhalation gas was prepared by the mixing of $\mathrm{H}_{2}$ gas and air, where the $\mathrm{H}_{2}$ gas was 


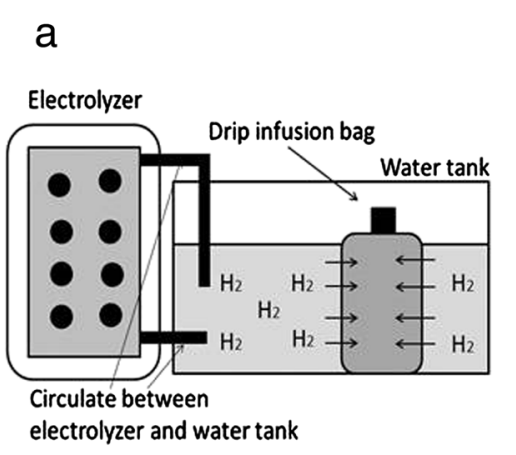

\section{b}

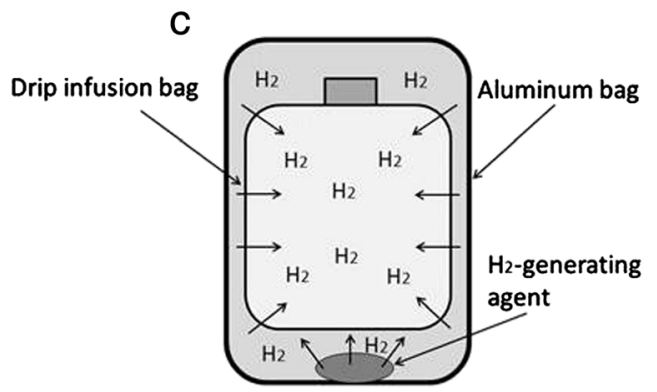

Fig. 2 Devices for $\mathrm{H}_{2}$-rich saline. $\mathbf{a}$ and $\mathbf{b}$ Method III: A polyethylene bag for drip infusion is immersed in an $\mathrm{H}_{2}$-containing water tank where the water is continuously electrolyzed and circulated during operation. $\mathrm{H}_{2}$ permeates through the polyethylene film and is dissolved into the solution without contamination. c Method IV: Non-woven fabric containing the $\mathrm{H}_{2}$-generating agent is moistened with a small amount of water, and then both a drip infusion bag and non-woven fabric are wrapped with aluminum foil under reduced pressure. The water reacts with the agent in the non-woven fabric to generate $\mathrm{H}_{2}$, and the $\mathrm{H}_{2}$ gas permeating through the polyethylene film in the bag dissolves into the solution

produced by the electrolysis of water, and the concentration was controlled under the detonation limit of the mixture of $\mathrm{H}_{2}$ gas and air (below $4 \%$ ).

\section{Measurement of $\mathrm{H}_{2}$ concentration}

The concentration of $\mathrm{H}_{2}$ gas in the water was measured using the methylene blue platinum colloid reagent-based titration method, as described previously [17], and verified using an electrochemical gas sensor (model DHD1-

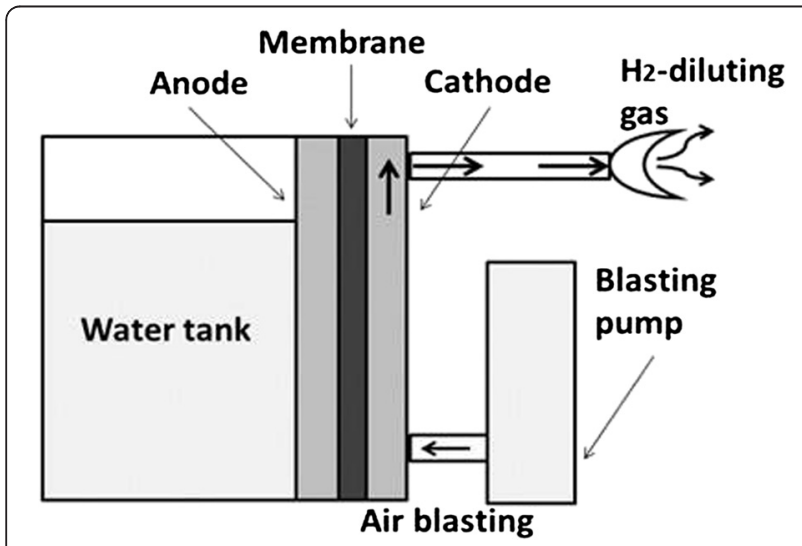

Fig. 3 Apparatus for $\mathrm{H}_{2}$ gas inhalation. The inhalation gas is prepared by mixing $\mathrm{H}_{2}$ gas and air, in which the $\mathrm{H}_{2}$ gas was produced by the electrolysis of water, and the concentration is controlled under the detonation limit of the mixture of $\mathrm{H}_{2}$ gas and air
1, DKK-TOA Corp., Tokyo, Japan). On the other hand, the concentration of $\mathrm{H}_{2}$ in the air was measured using an $\mathrm{H}_{2}$ gas sensor (FIS Inc., Hyogo, Japan).

\section{Statistical analysis}

The concentration of $\mathrm{H}_{2}$ gas in the water or air is presented as $\mathrm{ppm}(\mathrm{mg} / \mathrm{L}$, weight/volume) or \% (volume/ volume), respectively. Most of the experimental data are expressed as mean \pm standard deviation (mean $\pm \mathrm{SD}$ ) of more than three individual measurements. However, in the examination of $\mathrm{H}_{2}$-rich saline, the $\mathrm{H}_{2}$ concentration is expressed as an individual measurement to examine the differences between each bag and plastic vessel. The statistical significance was assessed by Student's paired or unpaired $t$-test for single comparisons or by one-way analysis of variance (ANOVA) followed by Fisher's LSD test for multiple comparisons. A $p$ value of less than 0.05 was considered to be statistically significant.

\section{Results/discussion}

$\mathrm{H}_{2}$ concentration of super-saturated $\mathrm{H}_{2}$ water prepared by Method I

$\mathrm{H}_{2}$ concentrations in the super-saturated $\mathrm{H}_{2}$ water prepared by Method I were measured at $10{ }^{\circ} \mathrm{C}, 15{ }^{\circ} \mathrm{C}$, and $25{ }^{\circ} \mathrm{C}$. As shown in Fig. 4a, at the same temperature, each $\mathrm{H}_{2}$ concentration after $24 \mathrm{~h}$ was significantly increased compared with each $\mathrm{H}_{2}$ concentration after $12 \mathrm{~h}$ 


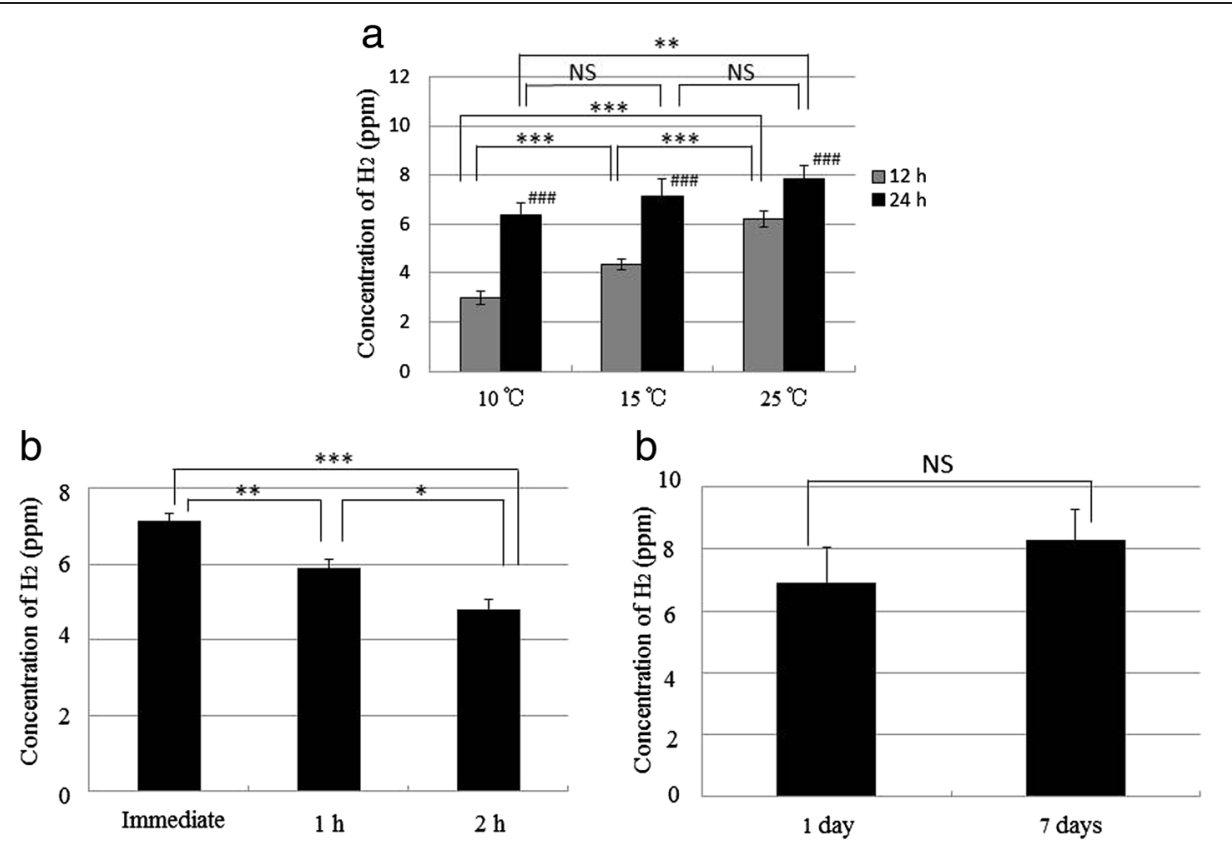

Fig. 4 Concentrations of $\mathrm{H}_{2}$ in the super-saturated $\mathrm{H}_{2}$-rich water prepared by Method I. a Concentrations of $\mathrm{H}_{2}$ measured at 10, 15, and $25^{\circ} \mathrm{C}$ after 12 and $24 \mathrm{~h}$ (\#\#\#p<0.001, $12 \mathrm{~h}$ vs. $24 \mathrm{~h}$ at the same temperature; ${ }^{* * *} \mathrm{p}<0.001,10^{\circ} \mathrm{C}$ vs. $15^{\circ} \mathrm{C}$ after $12 \mathrm{~h}, 15^{\circ} \mathrm{C}$ vs. $25^{\circ} \mathrm{C}$ after $12 \mathrm{~h}$, or $10^{\circ} \mathrm{C}$ vs. $25^{\circ} \mathrm{C}$ after $12 \mathrm{~h}$; ${ }^{* *} \mathrm{p}<0.01,10^{\circ} \mathrm{C}$ vs. $25^{\circ} \mathrm{C}$ after $24 \mathrm{~h}$ ). b Concentrations of $\mathrm{H}_{2}$ measured immediately after $24 \mathrm{~h}$, and then measured 1 or $2 \mathrm{~h}$ after the cap had been opened (*** $p<0.001$, Immediate vs. 2 h; ${ }^{* *} p<0.01$, Immediate vs. 1 h; ${ }^{*} p<0.05,1$ h vs. 2 h). c Concentrations of $\mathrm{H}_{2}$ measured after 1 or 7 days without opening. Data are presented as mean \pm standard deviation (SD) for 3-5 independent measurements

$(p<0.001)$. After $12 \mathrm{~h}, \mathrm{H}_{2}$ concentration at $25{ }^{\circ} \mathrm{C}$ was significantly increased compared with the concentration at $15{ }^{\circ} \mathrm{C}(p<0.001)$, and the concentration at $15{ }^{\circ} \mathrm{C}$ was significantly increased compared with that at $10{ }^{\circ} \mathrm{C}(p<0.001)$. In addition, after $24 \mathrm{~h}, \mathrm{H}_{2}$ concentration at $25{ }^{\circ} \mathrm{C}$ showed a significant increase compared with that at 10 ${ }^{\circ} \mathrm{C}(p<0.01)$. The $\mathrm{H}_{2}$ concentration after the opening of the PET bottle was also measured at room temperature. As shown in Fig. 4b, $\mathrm{H}_{2}$ concentration of the water was maintained at approximately $7 \mathrm{ppm}(7.13 \pm 0.22 \mathrm{ppm})$ after $24 \mathrm{~h}$ without opening the bottle; after the cap had been opened, the concentration after $1 \mathrm{~h}$ was significantly decreased compared with the concentration after immediately opening $(p<0.01)$. In addition, $\mathrm{H}_{2}$ concentration after $2 \mathrm{~h}$ was significantly decreased compared with that after $1 \mathrm{~h}(p<0.05)$. In our preliminary experiment after opening the bottle, the $\mathrm{H}_{2}$ concentrations in the bottle after 1 and $3 \mathrm{~h}$ were $4.53 \pm 0.15 \mathrm{ppm}$ and $2.10 \pm 0.10 \mathrm{ppm}$ (each $n=3$ ), respectively, when $150 \mathrm{~mL}$ of water was removed immediately after the termination of $\mathrm{H}_{2}$ gas production, and the same volume of water additionally removed after $1 \mathrm{~h}$ (data not shown). Furthermore, to examine the stability without opening, $\mathrm{H}_{2}$ concentration was measured after 7 days. As shown in Fig. $4 \mathrm{c}$, the $\mathrm{H}_{2}$ concentration of the water was maintained above $8 \mathrm{ppm}(8.30 \pm 0.98 \mathrm{ppm})$ after 7 days without the opening of the bottle. These results suggest that the $\mathrm{H}_{2}$ concentration is maintained for at least 7 days without opening, but the $\mathrm{H}_{2}$ water should be drunk within $2 \mathrm{~h}$ after opening. In addition, it is important that after opening, the bottle should not contain space for air in order to avoid the reduction of $\mathrm{H}_{2}$ concentration.

\section{$\mathrm{H}_{2}$ concentration of super-saturated $\mathrm{H}_{2}$ water prepared by Method II}

$\mathrm{H}_{2}$ concentrations in the super-saturated $\mathrm{H}_{2}$ water prepared by Method II were also measured at $10{ }^{\circ} \mathrm{C}, 15^{\circ} \mathrm{C}$, and $25{ }^{\circ} \mathrm{C}$. As shown in Fig. 5a, at the same temperature, each $\mathrm{H}_{2}$ concentration after $24 \mathrm{~h}$ was significantly increased compared with each $\mathrm{H}_{2}$ concentration after $10 \mathrm{~min}(p<0.001)$. After $10 \mathrm{~min}, \mathrm{H}_{2}$ concentration at $15{ }^{\circ} \mathrm{C}$ was significantly increased compared with the concentration at $10{ }^{\circ} \mathrm{C}(p<0.01)$, and the concentration at $25{ }^{\circ} \mathrm{C}$ was significantly increased compared with that at $10{ }^{\circ} \mathrm{C}(p<0.01)$. As shown in Fig. $5 \mathrm{~b}, \mathrm{H}_{2}$ concentration of the water was maintained at approximately $10 \mathrm{ppm}(10.08 \pm 0.34 \mathrm{ppm})$ after $24 \mathrm{~h}$ without opening of the bottle; after the cap had been opened, the concentration after $1 \mathrm{~h}$ showed significant decrease compared with that after immediately opening $(p<0.001)$, and the concentration after $2 \mathrm{~h}$ also showed significant decrease compared with that after $1 \mathrm{~h}(p<0.001)$. As shown in Fig. $5 \mathrm{c}$, the $\mathrm{H}_{2}$ concentration of the water was maintained at approximately 

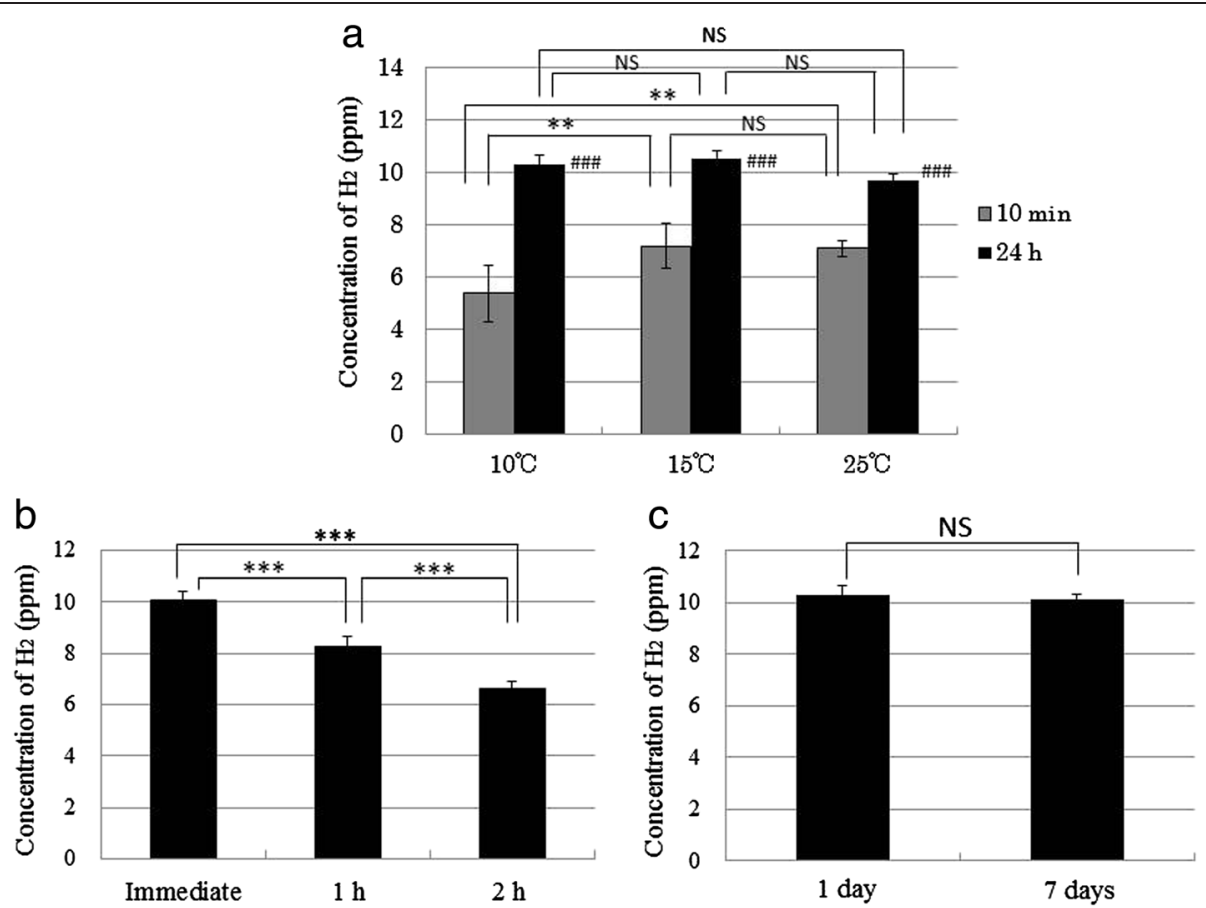

Fig. 5 Concentrations of $\mathrm{H}_{2}$ in the super-saturated $\mathrm{H}_{2}$-rich water prepared by Method II. a Concentrations of $\mathrm{H}_{2}$ measured at 10,15 , and $25{ }^{\circ} \mathrm{C}$

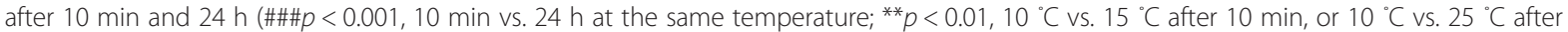
$10 \mathrm{~min})$. b Concentrations of $\mathrm{H}_{2}$ measured immediately after $24 \mathrm{~h}$, and then measured 1 or $2 \mathrm{~h}$ after the cap had been opened $\left({ }^{* * *} p<0.001\right.$, Immediate vs. 1 h, 1 h vs. 2 h, or Immediate vs. 2 h). c Concentrations of $\mathrm{H}_{2}$ measured after 1 or 7 days without opening. Data are presented as mean \pm standard deviation (SD) for 3-5 independent measurements

$10 \mathrm{ppm}(10.10 \pm 0.21 \mathrm{ppm})$ after 7 days without opening of the bottle. These results suggest that the $\mathrm{H}_{2}$ concentration prepared by this method is maintained for at least 7 days without opening, but the water should be drunk within $2 \mathrm{~h}$ of the cap being opened.
$\mathrm{H}_{2}$ concentration of $\mathrm{H}_{2}$-rich saline prepared by Method III The $\mathrm{H}_{2}$ concentrations of $\mathrm{H}_{2}$-rich saline prepared by Method III in the infusion bags were measured after immersion for $1,3,5$, and $10 \mathrm{~h}$ (Table 1 ). When the 3 types of bag (No. 1-3) were immersed for $10 \mathrm{~h}$,

Table 1 Details of drip infusion bag, dialysis fluid bag, and injection ampoule used in the experiment

\begin{tabular}{|c|c|c|c|c|c|}
\hline Experiment & No. & Trade name & Volume $(\mathrm{mL})$ & Purpose & Vendor \\
\hline \multirow[t]{3}{*}{$\bar{A}$} & 1 & $5 \%$ Glucose injection & 500 & $\mathrm{DI}$ & $T$ \\
\hline & 2 & Solulact (Lactate ringer sol.) & 500 & $\mathrm{Dl}$ & $\mathrm{T}$ \\
\hline & 3 & Isotonic sodium chloride sol. & 500 & $\mathrm{Dl}$ & $\mathrm{T}$ \\
\hline \multirow[t]{5}{*}{ B } & 1 & Otsuka normal saline & 500 & $\mathrm{Dl}$ & O \\
\hline & 2 & Hartman's sol. pH 8 (Lactate ringer sol.) & 500 & $\mathrm{Dl}$ & N \\
\hline & 3 & $5 \%$ Glucose injection (for animals) & 500 & $\mathrm{DI}$ & K \\
\hline & 4 & $7 \%$ Sodium hydrogen carbonate sol. (for animals) & 500 & $\mathrm{Dl}$ & K \\
\hline & 5 & Otsuka normal saline & 20 & I & $\mathrm{O}$ \\
\hline \multirow[t]{4}{*}{ C } & 1 & Otsuka normal saline & 500 & $\mathrm{Dl}$ & $\mathrm{O}$ \\
\hline & 2 & Midperiq & 2,000 & DF & $\mathrm{T}$ \\
\hline & 3 & Isotonic sodium chloride sol. & 100 & $\mathrm{Dl}$ & $\mathrm{T}$ \\
\hline & 4 & Isotonic sodium chloride sol. & 500 & $\mathrm{Dl}$ & $\mathrm{T}$ \\
\hline
\end{tabular}

A: Time-dependent concentration after immersion, B: Difference between types of containers, C: Storage stability in aluminum bag, sol.: Solution, DI: Drip infusion, I: Injection, DF: Dialysis fluid, T: Terumo Corp., Tokyo, Japan, O: Otsuka Pharmaceutical Co., Ltd., Tokyo, Japan, N: Nipro Corp., Osaka, Japan, K: Kyoritsu Seiyaku Corp., Tokyo, Japan 
approximately $1.0 \mathrm{ppm} \mathrm{H}_{2}$-rich saline was obtained (Fig. 6a). There were no differences in the $\mathrm{H}_{2}$ concentration between the types of drip infusion bag. These results demonstrated that it is necessary to immerse the drip infusion bag for at least $10 \mathrm{~h}$ in order to obtain $1.0 \mathrm{ppm} \mathrm{H}_{2}$-rich saline. To examine the permeability of $\mathrm{H}_{2}$ for the different polyethylene vessel materials, 5 types of vessels (No. 1-5) were immersed in the water bath for $5 \mathrm{~h}$, and the change in $\mathrm{H}_{2}$ concentration of each vessel was examined (Table 1 ). The $\mathrm{H}_{2}$ concentration of various infusion bags and polyethylene vessels depends on their thickness and the content of the solution. The $\mathrm{H}_{2}$ easily penetrated into the physiological saline (No. 1), but barely penetrated into the sodium hydrogen carbonate solution (No. 4). In addition, in the physiological saline, the $\mathrm{H}_{2}$ more easily penetrated into the $500 \mathrm{~mL}$ drip infusion bag (No. 1) than the $20 \mathrm{~mL}$ plastic injection ampoule (No. 5) (Fig. 6b). After the infusion bags had been immersed in the bath for 3, 5 , and $10 \mathrm{~h}$, they were removed and the changes in $\mathrm{H}_{2}$ concentration were measured until $5 \mathrm{~h}$ later. The $\mathrm{H}_{2}$ concentration of the drip infusion bag decreased from $1.0 \mathrm{ppm}$ to $0.6 \mathrm{ppm}$ after $1 \mathrm{~h}$ of removal from the water bath after immersion for $10 \mathrm{~h}$ (Fig. 6c). These results suggest that intravenous drip injection with these bags should be completed within $1 \mathrm{~h}$.
$\mathrm{H}_{2}$ concentration of $\mathrm{H}_{2}$-rich saline prepared by Method IV The $\mathrm{H}_{2}$ concentrations of 4 types of bag (No. 1-4) prepared by Method IV were also measured after 1, 3, 6, and 12 months in order to examine long-term preservation (Table 1). The $\mathrm{H}_{2}$ concentrations in the drip infusion bags (No. 1, 3, and 4) or dialysis fluid bag (No. 2) were maintained for 12 months, suggesting that the $\mathrm{H}_{2}$ rich saline prepared by this method could be used for 12 months (Fig. 7a).

\section{$\mathrm{H}_{2}$ concentration of gas introduced by inhaler}

We examined the $\mathrm{H}_{2}$ gas concentration for up to $3 \mathrm{~h}$ after starting use of the inhaler, because stability of the gas concentration is required in order to examine the performance of the gas inhaler. The $\mathrm{H}_{2}$ gas concentration in the inhaler was $2.91 \pm 0.08 \%$ after $0.5 \mathrm{~min}$, and a $\mathrm{H}_{2}$ gas concentration of approximately $3 \%$ was maintained for $3 \mathrm{~h}$. There was no significant difference among of the time points after starting (Fig. 7b). These results demonstrate that the $\mathrm{H}_{2}$ gas could be supplied stably for $3 \mathrm{~h}$ using this inhaler.

In summary, we prepared two types of supersaturated $\mathrm{H}_{2}$ water (7 or $10 \mathrm{ppm}$ ) for drinking. The concentrations in these waters were maintained for 7 days without opening, but the waters should be drunk within $2 \mathrm{~h}$ of the cap being opened. We also prepared

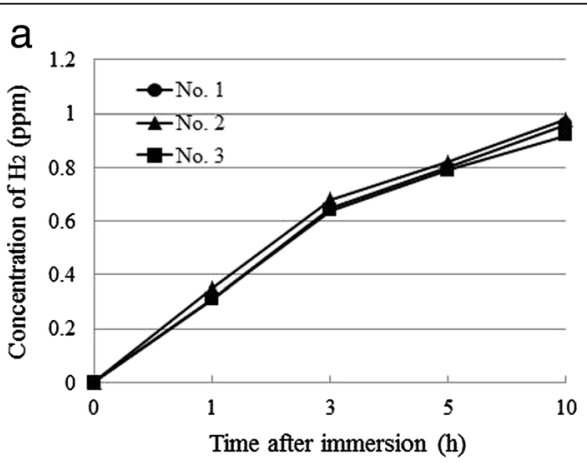

b

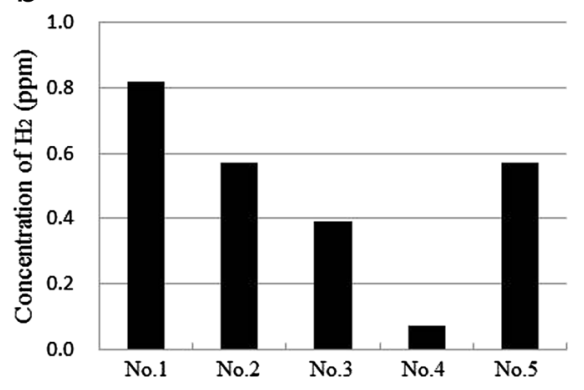

C

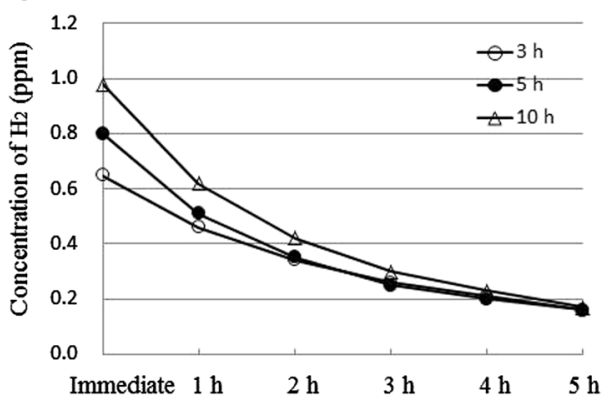

Fig. 6 Concentrations of $\mathrm{H}_{2}$ in the $\mathrm{H}_{2}$-rich saline prepared by Method III. a Concentrations of $\mathrm{H}_{2}$ measured at 1, 3, 5, and 10 h after immersion of the drip infusion bags. $\mathbf{b}$ Concentrations of $\mathrm{H}_{2}$ measured at $5 \mathrm{~h}$ after the immersion of each infusion bag and polyethylene vessel. c Concentrations of $\mathrm{H}_{2}$ measured at 1, 2, 3, 4, and $5 \mathrm{~h}$ after removal from the bath. Data are presented as individual measurements 


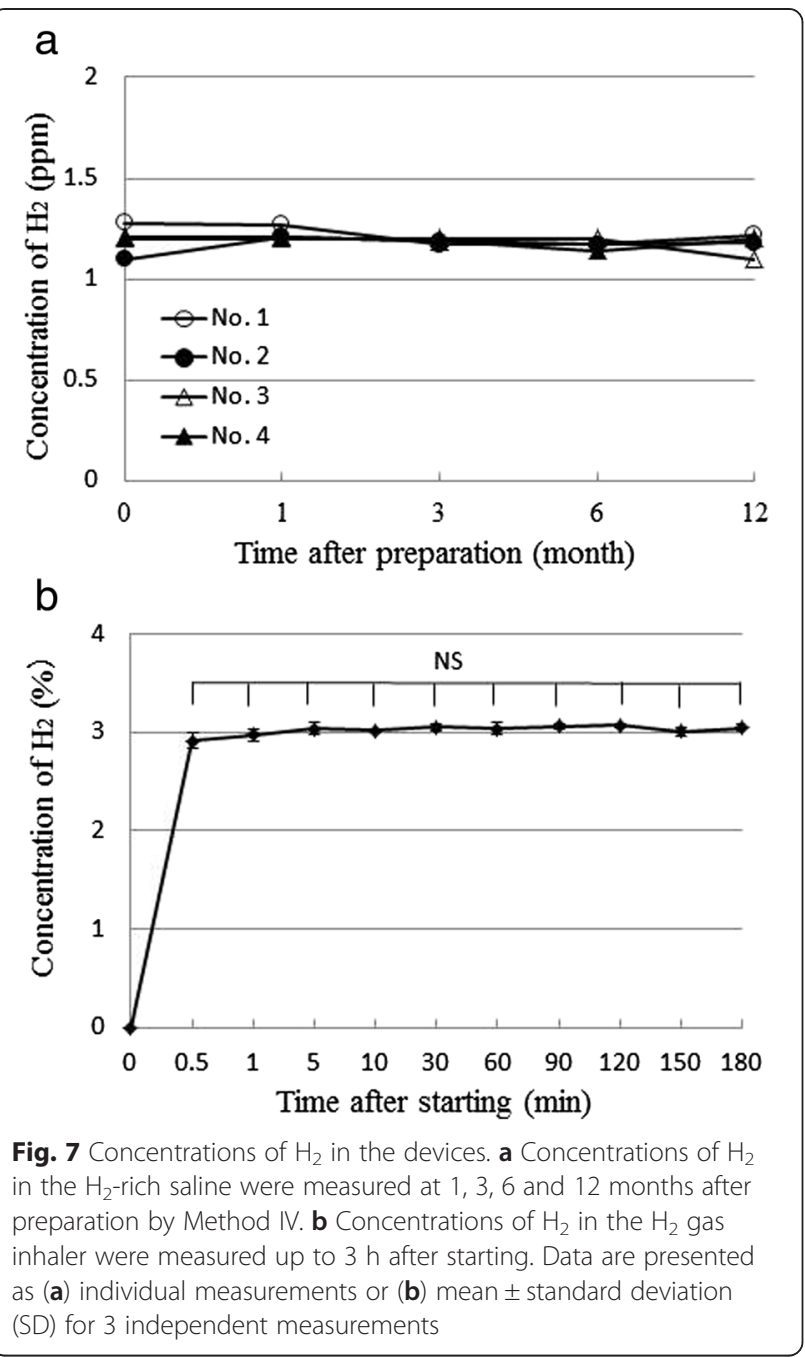

two types of $\mathrm{H}_{2}$-rich saline for injection. Although intravenous drip injection with the $\mathrm{H}_{2}$-rich saline should be completed within $1 \mathrm{~h}, \mathrm{H}_{2}$ concentrations in the saline prepared by aluminum foil (Method IV) were maintained for 12 months without opening. Moreover, we prepared $\mathrm{H}_{2}$-containing gas for inhalation. The gas was controlled under the detonation limit of the mixture of $\mathrm{H}_{2}$ gas and air, and the gas could be supplied stably for $3 \mathrm{~h}$. In a recent study, we examined the $\mathrm{H}_{2}$ concentration in rat tissue following administration of $\mathrm{H}_{2}$ via various routes [18]. We demonstrated that $\mathrm{H}_{2}$ concentrations in the tissues depend on the $\mathrm{H}_{2}$ concentration of the administered water or gas, and that the specific uptake of $\mathrm{H}_{2}$ in the tissues is due to the difference in administration route [18]. The present results suggest the importance in choosing the more efficient route of $\mathrm{H}_{2}$ treatment for each disease or tissue [18]. Therefore, we believe that the super-saturated $\mathrm{H}_{2}$ water (10 ppm) prepared by Method II, the $\mathrm{H}_{2}$-rich saline prepared by
Method IV, and the $\mathrm{H}_{2}$ gas prepared by our method are convenient and safe preparatory methods. The present results should contribute to the advance of non-clinical and clinical research in $\mathrm{H}_{2}$ medicine.

\section{Abbreviations}

$\mathrm{H}_{2}$ : molecular hydrogen; sol.: solution.

\section{Competing interests}

The authors declare that they have no competing interests.

\section{Authors' contributions}

RK and SH designed the study and analyzed the data. SH wrote the manuscript. RK, BS, and FS developed and prepared the various apparatuses for the ingestion of $\mathrm{H}_{2}$. TS, BS, and FS supported this study by collecting data and giving advice. All authors read and approved the final manuscript.

\section{Acknowledgments}

The authors are grateful to Dr. Yoshio Okamoto for his excellent advice in the writing of this manuscript.

Received: 3 August 2015 Accepted: 9 October 2015

Published online: 26 October 2015

\section{References}

1. Li J, Wang C, Zhang JH, Cai JM, Cao YP, Sun XJ. Hydrogen-rich saline improves memory function in a rat model of amyloid-beta-induced Alzheimer's disease by reduction of oxidative stress. Brain Res. 2010;1328:152-61.

2. Xie K, Yu Y, Zhang Z, Liu W, Pei Y, Xiang L, et al. Hydrogen gas improves survival rate and organ damage in zymosan-induced generalized inflammation model. Shock. 2010;34(5):495-501.

3. Yang Y, Li B, Liu C, Chuai Y, Lei J, Gao F, et al. Hydrogen-rich saline protects immunocytes from radiation-induced apoptosis. Med Sci Monit. 2012;18(4):BR144-148.

4. Song G, Li M, Sang H, Zhang L, Li X, Yao S, et al. Hydrogen-rich water decrease serum low-density lipoprotein cholesterol levels and improves high-density lipoprotein function in patients with potential metabolic syndrome. J Lipid Res. 2013;54(2):1884-93.

5. Itoh T, Fujita Y, Itoh M, Masuda A, Ohno K, Ichihara M, et al. Molecular hydrogen suppresses FcepsilonRI-mediated signal transduction and prevents degranulation of mast cells. Biochem Biophys Res Commun. 2009;389(4):651-8.

6. Nakao A, Toyoda Y, Sharma P, Evans M, Guthrie N. Effectiveness of hydrogen rich water on antioxidant status of subjects with potential metabolic syndrome: an open label pilot study. J Clin Biochem Nutr. 2010;46(2):140-9.

7. Yuan L, Chen X, Qian L, Shen J, Cai J. Administration of hydrogen-rich saline in mice with allogeneic hematopoietic stem-cell transplantation. Med Sci Monit. 2015;21:749-54.

8. Ohsawa I, Ishikawa M, Takahashi K, Watanabe M, Nishimaki K, Yamagata K, et al. Hydrogen acts as a therapeutic antioxidant by selectively reducing cytotoxic oxygen radicals. Nat Med. 2007;13(6):688-94.

9. Yoritaka A, Takanashi M, Hirayama M, Nakahara T, Ohta S, Hattori N. Pilot study of $\mathrm{H} 2$ therapy in Parkinson's disease. A randomized double-blind placebo-controlled trial. Mov Disord. 2013;28(6):836-9.

10. Ishibashi T, Sato B, Rikitake M, Seo T, Kurokawa R, Hara Y, et al. Consumption of water containing a high concentration of molecular hydrogen reduces oxidative stress and disease activity in patients with rheumatoid arthritis: an open-label pilot study. Med Gas Res. 2012;2(1):27.

11. Sakai T, Sato B, Hara K, Hara Y, Naritomi Y, Koyanagi S, et al. Consumption of water containing over $3.5 \mathrm{mg}$ of dissolved hydrogen could improve vascular endothelial function. Vasc Health Risk Manage. 2014;10:591-7.

12. Ishibashi T, Ichikawa M, Sato B, Shibata S, Hara Y, Naritomi $Y$, et al. Improvement of psoriasis-associated arthritis and skin lesions by treatment with molecular hydrogen: A report of three cases. Mol Med Rep. 2015;12(2):2757-64.

13. Ono H, Nishijima Y, Adachi N, Tachibana S, Chitoku S, Mukaihara S, et al. Improved brain MRI indices in the acute brain stem infarct sites treated 
with hydroxyl radical scavengers, Edaravone and hydrogen, as compared to Edaravone alone. A non-controlled study. Med Gas Res. 2011;1(1):12.

14. Ono H, Nishijima Y, Adachi N, Sakamoto M, Kudo Y, Nakazawa J, et al. Hydrogen (H2) treatment for acute erythymatous skin disease. A report of 4 patients with safety data and a non-controlled feasibility study with $\mathrm{H} 2$ concentration measurement on two volunteers. Med Gas Res. 2012;2(1):14.

15. Ishibashi T, Sato B, Shibata S, Sakai T, Hara Y, Naritomi Y, et al. Therapeutic efficacy of infused molecular hydrogen in saline on rheumatoid arthritis: A randomized, double-blind placebo-controlled pilot study. Int Immunopharmacol. 2014;21(1):468-73.

16. Terawaki H, Zhu WJ, Matsuyama Y, Terada T, Takahashi Y, Sakurai K, et al. Effect of hydrogen ( $\mathrm{H} 2)$-enriched solution on the albumin redox of hemodialysis patients. Hemodial Int. 2014;18(2):459-66.

17. Seo T, Kurokawa R, Sato B. A convenient method for determining the concentration of hydrogen in water: Use of methylene blue with colloidal platinum. Med Gas Res. 2012;2(1):1.

18. Liu C, Kurokawa R, Fujino M, Hirano S, Sato B, Li XK. Estimation of the hydrogen concentration in rat tissue using an airtight tube following the administration of hydrogen via various routes. Sci Rep. 2014;4:5485.

\section{Submit your next manuscript to BioMed Central and take full advantage of:}

- Convenient online submission

- Thorough peer review

- No space constraints or color figure charges

- Immediate publication on acceptance

- Inclusion in PubMed, CAS, Scopus and Google Scholar

- Research which is freely available for redistribution 